\title{
PENGEMBANGAN ALAT PERAGA PEMBELAJARAN MATEMATIKA SEKOLAH DASAR UNTUK MENINGKATKAN KEMAMPUAN BERPIKIR MATEMATIS SISWA
}

\author{
Sudarwanto $^{1)}$, Ibnu Hadi ${ }^{2}$ \\ Fakultas Matematika dan Ilmu Pengetahuan Alam Universitas Negeri Jakarta
}

\begin{abstract}
ABSTRAK
Kegiatan pengabdian kepada masyarakat ini dikuti oleh 22 orang guru sekolah dasar maupunpengasuh pondok pesantren yang ada di kecamatan Cibatu kabupaten garut Jawa Barat pada tanggal 20 September 2014. Alat peraga yang ditawarkan kepada peserta untuk dirancang, dibuat dan digunakan meliputi : Alat peraga pembelajaran matematika Kekekalan Luas, Alat peraga pembelajaran matematika Kekekalan Panjang, Alat peraga pembelajaran matematika Kekekalan Banyak, Alat peraga pembelajaran matematika untuk Percobaan dalam Teori Kemungkinan dan Alat peraga pembelajaran matematika untuk Pengukuran dalam Matematika.
\end{abstract}

Kata Kunci : Alat peraga, Matematika, Sekolah Dasar

\section{PENDAHULUAN}

\section{A. Latar Belakang}

Pembinaan guru merupakan salah satu penjabaran peran tanggung-jawab pemerintah, masyarakat dan organisasi profesi untuk mendorong guru mampu melaksanakan tugas dan fungsinya seoptimal mungkin. Adapun Tugas pokok dan fungsi seorang guru yaitu Bertanggung jawab kepada Kepala Sekolah dalam melaksanakan KBM, meliputi: Membuat kelengkapan mengajar dengan baik dan lengkap, Melaksanakan kegiatan pembelajaran, Melaksanakan kegiatan penilaian proses belajar, ulangan, dan ujian., Melaksanakan analisis hasil ulangan harian, Menyusun dan melaksanakan program perbaikan dan pengayaan, Mengisi daftar nilai anak didik, Melaksanakan kegiatan membimbing (pengimbasan pengetahuan), kepada guru lain dalam proses pembelajaran, Membuat alat pelajaran/alat peraga, Menumbuh kembangkan sikap menghargai karya seni, Mengikuti kegiatan pengembangan dan pemasyarakatan kurikulum, Melaksanakan tugas tertentu di sekolah, Mengadakan pengembangan program pembelajaran, Membuat catatan tentang kemajuan hasil belajar anak didik, Mengisi dan meneliti daftar hadir sebelum memulai pelajaran, Mengatur kebersihan ruang kelas dan sekitarnya, Mengumpul-kan dan menghitung angka kredit untuk kenaikan pangkat. Tugas pokok dan fungsi guru ini bersifat mengikat baik sebagai seorang guru maupun sebagai warga sekolah.

Berkaitan dengan pembelajaran Matematika di tingkat pendidikan dasar, mayoritas guru masih menerapan metode mengajar dengan mengunakan metode ceramah dan menekankan aspek hapalan terhadap rumus-rumus matematika.kondisi ini menyebabkan munculnya anggapan di sebagian besar siswa bahwa mateatika merupakan pelajaran yang sulit, tidak menarik dan membosankan, sehingga siswa cenderung tidak termotivasi untuk belajar matematika.

Pembelajaran Matematika yang menarik akan mengurangi tingkat ketidaktertarikan siswa akan matematika (Pujiati:2004, 2). Siswa yang tertarik belajar matematika maka akan termotivasi untuk belajar yang pada gilirannya prestasi belajarnyapun akan meningkat. Salah satu metode belajar yang saat ini diyakini oleh para ahli mampu meningkatkan ketertarikan siswa akan pelajaran matematika adalah metode belajar sambil bermain. Hal ini tidaklah aneh karena pada dasarnya anak-anak usia sekolah dasar adalah anak-anak yang tumbuh dalam lingkungan bermain.

Ketertarikan belajar matematika merupakan langkah awal munculnya minat dan motivasi belajar.Tujuan utama penggunaan alat peraga matematika adalah menimbulkan ketertarikan tersebut. Belajar sambil bermain memerlukan alat bantu peramainan yang berfungsi mengarahkan focus siswa untuk 
mencapai tujuan belajar. Alat bantu ini perlu direncanakan oleh guru agar tidak menyimpang dari tujuan yang ingin dicapai dan dibuat dengan mengikuti prinsip aman, sehat dan manfaat.

\section{B. Tujuan Kegiatan}

Kegiatan pengabdian kepada masyarakat ini bertujuan untuk mendampingi guru dan pengasuh pondok pesantren di kecamatan Cibatu Kabupaten Garut merencanakan dan membuat alat peraga pembelajaran matematika yang dapat digunakan untuk mengembangkan kemampuan berpikir matematis siswa sekolah dasar.

\section{KAJIAN TEORI}

\section{A. Pembelajaran Matematika}

Matematika berfungsi untuk mengembangkan kemampuan bernalar melalui kegiatan penyelidikan, eksplorasi dan eksperimen, sebagai alat pemecahan masalah melalui pola pikir dan model matematika serta sebagai alat komunikasi melalui simbol, tabel, grafik, dan diagram dalam menjelaskan gagasan. Matematika berfungsi mengembangkan kemampuan menghitung, mengukur, menamakan dan menggunakan rumus matematika sederhana yang diperlukan dalam kehidupan sehari-hari melalui materi bilangan, pengukuran, dan geometri. "Matematika juga berfungsi mengem-bangkan kemampuan mengkomunikasikan ide atau gagasan dengan menggunakan simbol, tabel, diagram, dan media lain", (Depdiknas, 2008: 134). Pembelajaran matematika adalah cara berpikir dan bernalar yang digunakan untuk memecahkan berbagai jenis persoalan dalam keseharian, sains, pemerintah, dan industri.

Dalam dokumen Standar Kompetensi mata pelajaran matematika untuk satuan SD dan MI pada kurikulum 2006 menyatakan tujuan pembelajaran matematika adalah:

1. Memahami konsep bilangan bulat dan pecahan, operasi hitung dan sifatsifatnya, serta menggunakan dalam pemecahan masalah kehidupan seharihari.

2. Memahami bangun datar dan bangun ruang sederhana, unsur-unsur dan sifat-sifatnya, serta menerapkannya dalam pemecahan masalah kehidupan sehari-hari.
3. Memahami konsep ukuran dan pengukuran berat, panjang, luas, volume, sudut, waktu, kecepatan, debit, serta mengaplikasikan dalam pemecahan masalah sehari-hari.

4. Memahami konsep koordinat untuk menentukan letak benda dan menggunakannya dalam pemecahan masalah sehari-hari.

5. Memahami konsep pengumpulan data, penyajian data dengan tabel, gambar dan grafik (diagram), mengurutkan data, rentangan data, rerata hitung, modus, serta menerapkannya dalam peme-cahan masalah sehari-hari.
a. Memiliki sikap menghargai matematika dan kegunaannya dalam kehidupan.
b. Memiliki kemampuan berpikir logis, kritis, dan kreatif, (Depdiknas, 2008: 235)

\section{Alat Peraga Pembelajaran Matematika}

Alat peraga merupakan bagian dari media, oleh karena itu istilah media perlu dipahami lebih dahulu sebelum dibahas mengenai pengertian alat peraga lebih lanjut. Media pembelajaran diartikan sebagai semua benda yang menjadi perantara terjadinya proses belajar, dapat berwujud perangkat lunak, maupun perangkat keras. Berdasarkan fungsinya media pengajaran dapat berbentuk alat peraga dan sarana.Alat peraga merupakan media pengajaran yang mengandung atau membawakan ciri-ciri dari konsep yang dipelajari.Alat peraga matematika adalah seperangkat benda konkret yang dirancang, dibuat, dihimpun atau disusun secara sengaja yang digunakan untuk membantu menanamkan atau mengembangkan konsep-konsep atau prinsip-prinsip dalam matematika (Pudjiati, 2004:4)

Manfaat media pengajaran dalam proses belajar siswa yaitu:

a. Pengajaran akan lebih menarik perhatian siswa sehingga dapat menumbuhkan motivasi belajar;

b. Bahan pengajaran akan lebih jelas maknanya sehingga dapat lebih dipahami oleh siswa dan memungkinkannya menguasai dan mencapai tujuan pengajaran; 
c. Metode mengajar akan lebih bervariasi, tidak semata-mata komunikasi verbal melalui penuturan kata-kata oleh guru, sehingga siswa tidak bosan dan guru tidak kehabisan tenaga, apalagi guru mengajar untuk setiap jam pelajaran;

d. Siswa lebih banyak melakukan kegiatan belajar, sebab tidak hanya mendengarkan uraian guru,tetapi juga aktifitas lain seperti mengamati, melakukan, mendemonstrasikan dan lain-lain (Sudjana \& Rivai, 2002: 2)

Penggunaan alat peraga dan media lainnya dalam pembelajaran matematika (khususnya dalam memberikan penanaman konsep) akan membawa hasil enam kali lebih baik dan lebih cepat dibandingkan dengan pengajaran drill tanpa konsep (Sukayati dan Agus Suharjana: 2009,6). Semua benda yang digunakan sebagai alat dalam pembelajaran matematika disebut alat peraga matematika.alat peraga merupakan media pembelajaran yang mengandung atau membawakan ciri-ciri konsep yang dipelajari.

Fungsi utama alat peraga matematika adalah untuk menurunkan keabstrakan dari konsep, agar anak mampu menangkap arti sebenarnya dari konsep yang dipelajari. Dengan melihat, meraba, dan memanipulasi alat peraga maka anak mempunyai pengalaman nyata dalam kehidupan tentang arti konsep.

\section{B. Berpikir Matematis}

Secara umum, berpikir dapat didefinisikan sebagai kemampuan untuk menghubung-hubungkan (asosiasi) sesuatu dengan sesuatu yang lainnya untuk memecahkan suatu persoalan atau permasalahan. Hasil dari menghubunghubungkan ini antara lain:

1. Memecahkan masalah

2. Gagasan-gagasan

3. Ide-ide.

Berpikir matematika hanyalah salah satu aspek pemikiran pada umumnya.Oleh karena itu, pertanyaan tentang berpikir matematis dapat meningkatkan pertanyaan-pertanyaan tentang semua jenis berpikir. Mekanisme proses berpikir matematis sama dengan proses kognisi pada umumnya, yaitu meliputi penterjemahan, mengintegrasikan, perencanaan, dan pelaksanaan. Dalam mekanisme proses berpikir matematis terdiri dari dua strategi yaitu strategi penerjemahan langsung dan strategi model permasalahan.

Andrew Noyes (2007) dalam bukunya yang berjudul "Rethinking School Mathematics " menyatakan bahwa "Many children are trained to do mathematical calculations rather than being educated to think mathematically". Dalam pembelajaran matematika, banyak siswa dilatih untuk melakukan perhitungan matematika dibandingkan dengan didik untuk berpikir matematis.Terdapat perbedaan antara "melakukan matematika" dengan "berpikir matematis". Untuk memahami perbedaan keduanya, matematika bisa dilihat dari tiga sudut pandang, yaitu: (1) posisi matematika, (2) aspek matematika, dan (3) jenis pengetahuan matematika.

\section{HASIL DAN PEMBAHASAN}

Kegiatan pengabdian kepada masyarakat ini terkait dengan instansi bidang pendidikan dalam hal ini Departemen Pendidikan Nasional maupun Departemen Agama sebagai upaya meningkatkan sumberdaya manusia, dalam hal ini guru sekolah dasar dan pengasuh ponok pesantren di Kecamatan Cibatu Kabupaten Garut Provinsi Jawa Barat. Hasil kegiatan ini diharapkan dapat membantu mengembangkan kemampuan guru dalam melaksanakan proses belajar mengajar melalui penerapan metode pembelajaran yang menarik dan mampu menumbuhkembangkan kemampuan matematis siswa sehingga guru mampu menjadi guru yang professional dan tidak ketinggalan jaman.

Kegiatan pengabdian kepada masyarakat ini dikuti oleh 22 orang guru sekolah dasar maupunpengasuh pondok pesantren yang ada di kecamatan Cibatu kabupaten garut Jawa Barat pada tanggal 20 September 2014. Berdasarkan dialog yang dilakukan sebelum kegiatan workshop dilakukan maka diperoleh informasi yang disampaikan oleh peserta dapat di kelompokkan sebagai berikut:

1. Sebagian besar (14 orang) peserta dalam mengajar masih bersifat induktif dan menggunakan metode ceramah, bahkan hampir sebagian besar guru tidak pernah menggunakan alat peraga pembelajaran.

2. Sebagian peserta menganggap buku pelajaran matematika sekolah dasar 
sudah mencukupi untuk digunakan sebagai sumber belajar sedang sebagaian yang lain mengatakan bahwa sumber belajar yang ada masih sangat kurang dan kurang bervariasi, serta sebagian besar peserta tidak tahu cara mencari sumber belajar khususnya sumber belajar yang secara spesifik mengarah pada pembelajaran matematika di Sekolah Dasar yang menggunakan konsep kontekstual, menggunakan alat peraga dan berbasis pada aktifitas siswa secara mandiri.

3. Mayoritas peserta (18 orang) belum pernah menggunakan alat peraga pembelajaran dikarenakan kondisi lingkungan sekolah yang tidak mendukung serta berangapan bahwa untuk membuat alat peraga pembelajaran matematika yang dibutuhkan dirasa sulit dan mahal.

4. Sebagian Peserta/guru merasa bahwa kemampuan siswa untuk diajar lebih lanjut terbatas karena kurangnya daya dukung ekonomi keluarga.

5. Sebagian peserta mempunyai pekerjaan lain selain guru sehingga waktu yang tersisa untuk menyiapkan pembelajaran sudah tidak banyak lagi.

Dari beberapa permasalahan yang disampaikan peserta di atas telah disampaikan beberapa alternatif pemecahan masalah yang disampikan oleh nara sumber sebagai berikut:

1. Metode ceramah memang diperlukan namun perlu diikuti dengan metode lain seperti metode penemuan maupun diskusi. Hal ini perlu dilakukan untuk menghindari kejenuhan maupun menurunnya daya kritis siswa akibat cara belajar yang tunggal dan lebih banyak bertumpu pada ketrampilan dan aktifitas yang monoton dan melupakan unsur bermain pada diri anak.

2. Sumber belajar dapat dicari apabila guru menjalin komunikasi dengan pihak lain seperti MGMP ataupun memanfaatkan fasilitas internet untuk mencari sumber belajar yang ada di internet. Permasalahan penggunaan bahasa yang mayoritas sumber belajar yang ada di internet berbahasa inggris dapat diantisipasi dengan memanfaatkan mailing list ataupun kamus online yang ada.

3. Meningkatkan motivasi guru dalam mengajar dengan menggunakan metode maupun alat peraga pembelajaran yang sesuai dengan konteks dan materi pembelajaran dapat dilakukan dengan cara memandang dan melaksanakan kegiatan mengajar sebagai bentuk prestasi diri dan ibadah/amanah yang merupakan tanggung jawab personal terhadap sumpah jabatan dan profesionalismenya. Sehingga filosofi bekerja semaksimal dan seprofesional mungkin selalu dipegang teguh setiap guru.

4. Setiap siswa mempunyai potensi untuk mengembangkan kemampuan berpikirnya dan tidak sepenuhnya tergantung pada kondisi ekonomi keluarganya. Potensi ini perlu didukung, difasilitasi dan didorong oleh guru dengan cara salah satunya adalah penyediaan berbagai sumber belajar yang diperlukan, untuk itu guru perlu kreatif dan berkemauan keras untuk memotivasi belajar siswa.

5. Beban hidup yang tinggi memang menuntut pemenuhan kebutuhan yang tinggi pula sehingga wajar apabila seseorang mempunyai lebih dari satu profesi karena didorong oleh alasan kebutuhan ekonomi. Namun demikian profesi guru merupakan profesi yang amat mulai sehingga tidak begitu pas apabila profesi in hanya dihitung dari sisi finansial.

Profesi guru memberi guru akses yang baik dan mudah kepada masyarakat sehingga guru yang cerdas akan mampu mengelola akses tersebut untuk meraih materi pendukung penunjang profesi. Dengan pengelolaan yang baik pekerjaan lain diluar profesinya sebagai guru akan dapat dilaksanakan dengan memanfaat-kan waktu yang efesien sehingga guru masih mempunyai cukup waktu untuk mengembangkan dirinya berkaitan dengan profesinya.

Alternatif pemecahan masalah yang dihadapi guru seperti yang yang 
disampaikanoleh nara sumber tersebut peserta diharapkan mampu melihat kembali jalan keluar lain yang mungkin dapat diterapkan untuk mengatasi permasalahannya tersebut. Kegiatan selanjutnya adalah penyajian teori dan konsep alat peraga pembelajaran dilanjutkan dengan penyampaian materi mengenai berbagai macam jenis alat perga pembelajaran yang mungkin untuk di buat oleh guru beserta cakupan dan karakteristik materi pelajaran yang memungkin-kan pemanfaatan alat peraga pembelajaran tersebut.Pemanfaatan alat peraga pembelajaran diperlukan karena hal ini dimaksudkan agar siswa segera terlibat dalam proses artinya materi pelajaran matematika yang disampaikan oleh guru masih dapat dipahami atau bermakna bagi siswa. Selain daripada itu, diharapkan bahwa pemnafaatan alat peraga pembelajaran matematika akan membantu memecahkan soal-soal latihan dengan menggunakan lebih dari satu cara atau strategi serta melibatkan lebih dari satu aktifitas berpikir matematis. Sehingga siswa merasa tertarik dan sadar akan betapa kayanya cara dalam matematika dalam menyelesaikan suatu permasalahan. Diharapkan akan timbul penghargaan siswa tentang peranan matematika dalam kehidupan dan dalam menyelesaikan berbagai masalah dalam kehidupan.

Nara sumber mendemontrasikan pemanfaat alat peraga Pembelajaran Matematika yang selanjutnya coba ditawarkankepada guru untuk mempraktekkannya. Alat peraga yang digunakan tersebut mempunyai kemungkinan besar guru dapat membuatnya antara lain :

a. Alat peraga pembelajaran matematika Kekekalan Luas.

Luas daerah persegi panjang, luas daerah bujursangkar, luas daerah segitiga, luas daerah trapesium, uraian $\mathrm{a}(\mathrm{b}+\mathrm{c})$, uraian $(\mathrm{x}+\mathrm{a})(\mathrm{x}+$ b), uraian $(a+b) 2$, uraian $a 2-b 2$, jumlah ukuran sudut dalam segitiga, jumlah ukuran sudut dalam segiempat tangram.

b. Alat peraga pembelajaran matematika Kekekalan Panjang

Tangga garis bilangan, pita garis bilangan, neraca bilangan, mistar hitung, dan batang Cuisenaire.

c. Alat peraga pembelajaran matematika Kekekalan Banyak Abacus biji (Romawi, Rusia dan Cina/Jepang) lidi, dan kartu nilai tempat

d. Alat peraga pembelajaran matematika untuk Percobaan dalam Teori Kemungkinan

Uang logam, dadu (bermata dan berwarna), bidang empat ( bermata dan berwarna) paku payung, kartu (domino dan bridge), bola berwarna

e. Alat peraga pembelajaran matematika untuk Pengukuran dalam Matematika

Meteran, busur derajat, roda meteran, jangka sorong (segmat), hypsometer, dan klinometer.

f. Alat peraga pembelajaran matematika Bangun-bangun Geometri

Macam-macam daerah segitiga, macam-macam daerah segiempat, pengubinan daerah segitiga, pengubinan daerah segiempat, pengubinan daerah lingkaran, pengubinan daerah pengubinan huruf abjad latin.

Hasil dari pembuatan alat peraga dapat dibawa pulang peserta untuk digunakan dalam kegiatan belajar mengajar di kelasnya.

\section{KESIMPULAN}

Alat peraga pembelajaran adalah bahan, alat, maupun metode/teknik yang digunakan dalam kegiatan belajar mengajar dengan maksud agar proses interaksi komunikasi edukatif antara guru dan anak didik dapat berlangsung secara efektif dan efesien sesuai dengan tujuan pengajaran yang telah dicita-citakan. Dalam Suatu proses belajar mengajar, dua unsur yang amat penting adalah metode mengajar dan Alat peraga pembelajaran. 
Kegiatan pengabdian kepada masyarakat ini dirasakan oleh peserta sebagai suatu kegiatan yang sangat bermanfaat dan memberikan informasi baru yang diharapkan mampu memberikan pencerahan dan bekal pengembangan profesi serta pengayaan pengatahuan yang berkaitan dengan metodologi pembelajaran bagi peserta.

\section{DAFTAR PUSTAKA}

[1] Pujiati., Dra., M.Pd. (2004). Penggunaan Alat Peraga Dalam Pembelajaran Matematika SMP. PPPPTK Matematika. Yogyakarta.

[2] Depdiknas. 2008a. Panduan Pengembangan Bahan Ajar. Jakarta: Direktorat Pembinaan SMA, Dirjen Mandikdasmen, Depdiknas.

[3] Depdiknas. 2008b. Peraturan Menteri Pendidikan Nasional RI Nomor 2 tahun 2008 Tentang Buku. Jakarta: Depdiknas.

[4] Wijaya, Aryadi. 2012. Pendidikan Matematika Realistik, Suatu Alternatif Pendekatan Pembelajaran Matematika. Yogyakarta: Graha Ilmu.

[5] Sukayati dan Agus Suharjana, Pemanfaatan Alat Peraga Matematika Dalam Pembelajaran di SD, P4TK Matematika, Yogyakarata, 2009 